\title{
Total Organic Carbon in Red Paleosoils and Basalts from ODP Leg 197 and their Potential use as Suitable Models for Mars Soil Analogues
}

\author{
Rosalba Bonaccorsi \\ Department of Geological, Environmental and Marine Sciences \\ (DiSGAM), University of Trieste. Via E. Weiss, 2-34127, TS Italy. \\ E-mail: bonaccor@univ.trieste.it
}

\begin{abstract}
.
Although on Mars no near-surface life has been detected, some preservation of organics with depth is expected. Stratigraphic and geochemical information on low-organic carbon (50\% samples with Total Organic Carbon $=0.05-0.12 \%$ ) Fe-oxides/oxyhydroxide-rich horizons of deeply buried red paleosoils (late Paleocene-early Eocene(?) in age) are presented here. They were retrieved during the Ocean Drilling Program (ODP) Leg 197 (Emperor Seamounts, North Pacific Transect). Organic traces in Hole 1205A are likely to reflect a complex history of paleosoil formation. Materials from an extremely deep (sub-basement) diagenetic setting, i.e., 46.8 to 309.9 meters below seafloor (mbsf), could represent a model for possible deep subsurface soils preserved on Mars.
\end{abstract}

\section{Introduction and Background}

Why are Leg 197 red paleosoils relevant to Mars? The detection of past life (e.g., a deep fossil record and biological signatures) buried deep beneath the surface of a planet is a fundamental step towards understanding the presence and evolution of life on that planet. Although not unequivocal, the present-day near-surface Martian soil is thought not to contain life and organics due to very low atmospheric pressure (i.e., 4-7 mbar) and low surface temperatures (e.g., down to $-125^{\circ} \mathrm{C}$ ) and the presence of an oxidant (i.e., peroxide/superoxide) e.g. (Zent \& McKay 1994). The interaction of the oxidants with UV radiation probably destroys complex organic materials, that otherwise should accumulate at the Mars surface by meteorites bombardment. It is thought that the oxidant is created at the surface of the soil by the interaction of UV radiation and the soil itself, suggesting that the oxidant concentration decreases with depth (Kanavarioti \& Mancinelli 1990). Present-day conditions on Mars and its near-surface soil biology and biogeochemistry are drastically different from those on Earth. On the other hand, past environmental surface conditions on an ancient Mars should have been quite different (i.e., wetter and warmer climate) than today as suggested from observations of landscapes with paleo-coastlines (indicative of an ocean basin) and extensively developed Valley networks e.g. (Carr 1999).

Thus, if life existed on a wetter and warmer early Mars and organic material was produced, then organic sources might be still detectable at some depth. 
In fact, conditions completely different from the present-day Mars surface and atmosphere could occur beneath some tens- to hundreds of meters of depth (Kanavarioti \& Mancinelli 1990; Mancinelli 2000). Hence, the search for possible organic material in deeply buried fossil soil from hard rock cores on Earth should be considered relevant to the establishment of a new model for subsurface Martian soil. Then, geomicrobiological information obtained from the study of such analog could be useful for the selection e.g. (Gilmore et al. 1998) of Mars landing sites and future Mars deep drilling/sample return missions (Mancinelli 2000).

During Leg 197 (Tarduno et al. 2002) red claystone units (herein referred as to paleosoil or fossil soil horizons) were retrieved from a rotary core barrel (RCB) throughout volcanic basement at Site 1205 (Nintoku Seamount, 41 20.00'N; $170^{\circ} 22.70^{\prime} \mathrm{E}$ ) and Site 1206 (Koko Seamount, 34 ${ }^{\circ} 55.55^{\prime} \mathrm{N} ; 1_{172^{\circ}} 8.75^{\prime} \mathrm{E}$ ) (Fig. 1 and Fig. 2). A total of 30 lithologic units composed of red soil/deeply weathered flow tops and lava flows (eruptive sub-basement Rock units) were cored at Site 1205 (Fig. 2) and Site 1206. These units contain a few cm-thick (Cores 1971205A-6R-3 to $-43 \mathrm{R}-4$; at 45.8 to $286.0 \mathrm{mbsf}$ ) to metre-thick (Hole 197-1206A$40 \mathrm{R}-1,101 \mathrm{~cm}$ to $40 \mathrm{R}-3,77 \mathrm{~cm}$; at 307.5 to $309.9 \mathrm{mbsf}$ ) soil horizons

The horizons consist of Fe-oxides/oxy-hydroxides such as hematite $\left(\mathrm{Fe}_{2} \mathrm{O}_{3}\right)$ opaque minerals, some feldspar, palagonite and smectite (from altered volcanic glass), and other clay minerals. Red-brown horizons are structureless to faintly layered (e.g., Fig. 4b, and Fig. 4c) and/or mottled with matrix hosting mmto dm-sized clasts (Breccia and Aphyric Plagioclase-Olivine rocks) at various stages of alteration (Fig. 4c). Vertical cracks/veins with zeolite geminate crystals and cm-sized vesicles are partially filled with gray crust (silagonite) and indicate pre-burial (low temperature i.e., 30-60 C) pedogenetic alteration with some (post-burial) hydrothermal alteration (moderate temperature, e.g., 60-100 C) (Tarduno et al. 2002).

Although the discovery of deep red-brown silty-claystone units dates back to the mid-1970's (Karpoff 1980; Premoli-Silva et al. 1993; Holmes 1995), the potential for preservation of organic matter in these igneous derived paleosoils has been overlooked, and depositional settings of the oxic units have been inferred mostly from petrologic observations (Karpoff 1980; Premoli-Silva et al. 1993; Holmes 1995). Low but still detectable amounts of total organic carbon (TOC), i.e., $0.04-0.12 \%$ wt, were found in the red paleosoil beds throughout Hole 1205A (Tarduno et al. 2002) and Hole 1206A (Bonaccorsi 2002). It is suggested here that evidence of $\mathrm{C}_{\text {org }}$ in such an isolated deep setting make the red soils, which are decoupled from the ocean and the atmosphere, a useful test bed for future studies on deep Earth biospheres. Finally, these soils could represent terrestrial counterparts (Bonaccorsi 2002) of Martian regolith soil formed under wetter/warmer climates on an early Mars, and plausible models for astrobiologyrelevant investigations (Morrison \& Schmidt 1999).

\section{Materials and Methods}

Full details about the drilling sites, and coring procedures are accessible online (Tarduno et al. 2002). In order to explore compositional variability within the soil structure, multiple samples (cm-to sub $\mathrm{cm}$ - spaced) were extracted from 14 


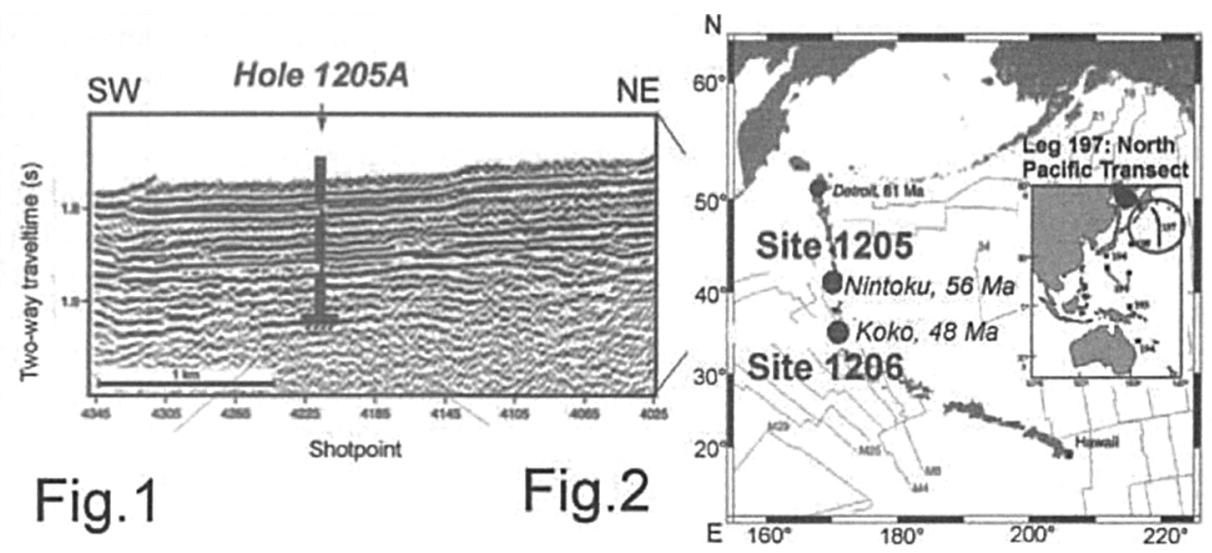

Figure 1. N. Pacific Transect and Location of Leg 197 Site 1205 (Nintoku Seamount) and Site 1206 (Koko Seamount).

Figure 2. Hole 1205A Seismic stratigraphy. Survey3-line4, frequency-wavenumber migrated; trace-to-trace distance is $\sim 9.9 \mathrm{~m}$; vertical exaggeration at the seafloor is $\sim 3.5: 1$; bottom of Hole $1205 \mathrm{~A}$ $\sim 1.92 \mathrm{~s}$ two-way traveltime.

soil beds throughout Hole 1205A. A total of 38 crushed freeze-dried samples (a. $5 \mathrm{mg}$ ) were analysed for total nitrogen, total carbon (TC) and inorganic carbon (IC) with a Carlo Erba NCS analyser NA 1500 and a coulometer operating onboard the JOIDES Resolution. Total organic carbon values (\%wt) were calculated by the difference between TC and IC (carbonate carbon) (Shipley et al. 1995). The analytical precision for analysis of TC and IC is $<1 \%$ ( $1 \sigma$ standard deviations) and the typical error combined for the two instruments is $2 \%$. The low-level standard ODP6 $(\mathrm{N}=0.11 \pm 0.05 \%$; $\mathrm{C}=3.2 \pm 0.005 \%$; $\mathrm{n}=60)$ was used to improve the precision of low-TOC measurements and as a reference for estimation of the detection limit (i.e., Method Detection Limit (MDL). MDL was calculated as $t^{*} S$, where $S$ is the standard deviation of the replicate analyses (i.e., 0.005) and $t$ is the Student's value for 60 degrees of freedom at $99 \%$ confidence limit $(t=2.39)$. Finally, in order to confirm results from shipboard analyses one sample (at 197-1205A-36R-1, 10-11 cm; Fig. 4a) was replicated using an Elemental analyser CHNS (Carlo Erba EA-1110/ Finnigan ConFlo-II) coupled with a Finnigan Delta Plus Mass Spectrometer.

\section{Results}

\subsection{Organic Matter Detection}

In Hole $1205 \mathrm{~A} 50 \%$ of samples $(\mathrm{n}=18)$ contain quite low- $\mathrm{C}_{\text {org }}$ ( $\left.\mathrm{TOC} \leq 0.04 \%\right)$, the most of which (0.01-0.02\%) are close to the lower end of the MDL (i.e., 0.012 \%wt). More specifically, soil samples from Core 197-1205A-6R, Core 197-1205A15R, and Core 197-1205A-19R (45.8-114.3 mbsf) and from Core 197-1205A- 
28R, and Core 197-1205A-29R (187.0-200.2 mbsf) contain the lowest amount of $\mathrm{C}_{\text {org }}(\mathrm{TOC}=0.01-0.04 \%, 0.025 \pm 0.012 \%, \mathrm{n}=7$ and $0.01-0.04 \% ; 0.020 \pm 0.011 \%$, $\mathrm{n}=8$, respectively). Instead, samples analysed from Core 197-1205A-23R, Core 197-1205A-25R, and Core 197-1205A-26R (143.8-171.5 mbsf), and Core 1971205A-33R, Core 197-1205A-36R, and Core 197-1205A-40R (229.3-277.9 mbsf) contain the highest \%wt (TOC $=0.03-0.12 \% ; 0.057 \pm 0.023, \mathrm{n}=12$ and $0.08-0.11 \%$; $0.090 \pm 0.014, \mathrm{n}=12$, respectively). The shipboard and shore-based analysis of Sample 197-1205A-36R-1, 10-11 cm) (Fig. 4a) gave quite similar results $($ TOC $=$ $0.10 \%$ and $\mathrm{TOC}=0.096 \pm 0.006 \%, \mathrm{n}=2$, respectively). Nitrogen is extremely low $(0.000-0.006 \%)$ and under the analytical detection limits for shore-based analyses $(0.119 \% \mathrm{wt})$. Hence, no use of the $\mathrm{C} / \mathrm{N}$ ratio was made for determining the source of the organic matter detected throughout Hole 1205A.

\subsection{Downhole Distribution of $\mathbf{C}_{\text {org }}$}

In Fig. 4a it can be clearly seen that, since $90 \%$ of compositional $\%$ wt values are within the error margin of $\pm 0.02 \%$, groups of soil and single soil horizons mostly contain the same amount of $\mathrm{C}_{\text {org }}$. The only exception is for Unit 10 (red to brown layered soil and baked breccia) in Core 197-1205A-23R (101.06 to $101.18 \mathrm{~m}$, Fig. 3) and the basal breccia of Subunit 19c, which also contains a significant amount of organic carbon (up to $0.10 \mathrm{wt} \%$ ). In addition, $\mathrm{C}_{\text {org }}$ averages at two depth intervals (i.e., 143.8-171.5 mbsf and 143.8-171.5 mbsf) were significantly different ( $\mathrm{z}$-test, two tails; $\mathrm{z}=4.75, \mathrm{P}<0.001$ ) and the null hypothesis $\mathrm{H}_{0}$ (i.e., there is no statistical difference between the \%TOC mean of two groups of samples) can be rejected. Two types of red-clay materials can also be distinguished by their $\mathrm{C}_{\text {org }}$ vs. carbonates $\left(\mathrm{CaCO}_{3}=0.03-0.12 \%, 0.061 \pm 0.021, \mathrm{n}\right.$ $=38$ ) content. This relationship defines relatively high-TOC/low- $\mathrm{CaCO}_{3}$ (Core 197-1205A-23R, and Core 197-1205A-36R), and ultra low-TOC/relatively high$\mathrm{CaCO}_{3}$ (Core 197-1205A-6R, Core 197-1205A-15R, and Core 197-1205A-29R) compositional fields.

\section{Discussion}

\subsection{Claystone units and Organic Carbon throughout Hole 1205A}

Red-brown claystone units from Leg 197 are similar in colour (e.g., 10R 2/2 to 5 YR $3 / 2$ ), texture, and composition to some units described from DSDP Leg 55 (a 10-cm interval at Hole 432A, Nintoku Seamount) (Karpoff 1980) and ODP Leg 144 (sequences up to $28 \mathrm{~m}$-thick at Site 871, Limalok Guyot) (Premoli-Silva et al. 1993; Holmes 1995). Those sequences were identified as paleosoil with preserved Horizon C (at contact with the weathered parent rock) and Horizon B (between Horizon A and Horizon C). Although most of the downhole/downsection $\mathrm{C}_{\text {org }}$ data does not show any discernible trend with depth, there are two assemblages of soil units containing $\leq 0.04 \%$ (constant and very-low values) and $0.05-0.12 \%$ TOC (constant and relatively-high values), which alternates from bottom toward the top of Hole 1205A (Fig. 4a). At this stage, it is only possible to speculate on the meaning of such a constant distribution of organic matter throughout the different soil units. Firstly, the quite similar amount of TOC within the same cm-thick soil beds (Fig. 4a, and Fig. 4b) could be the result of their 


\section{Hole 1205A Nintoku Seamount}

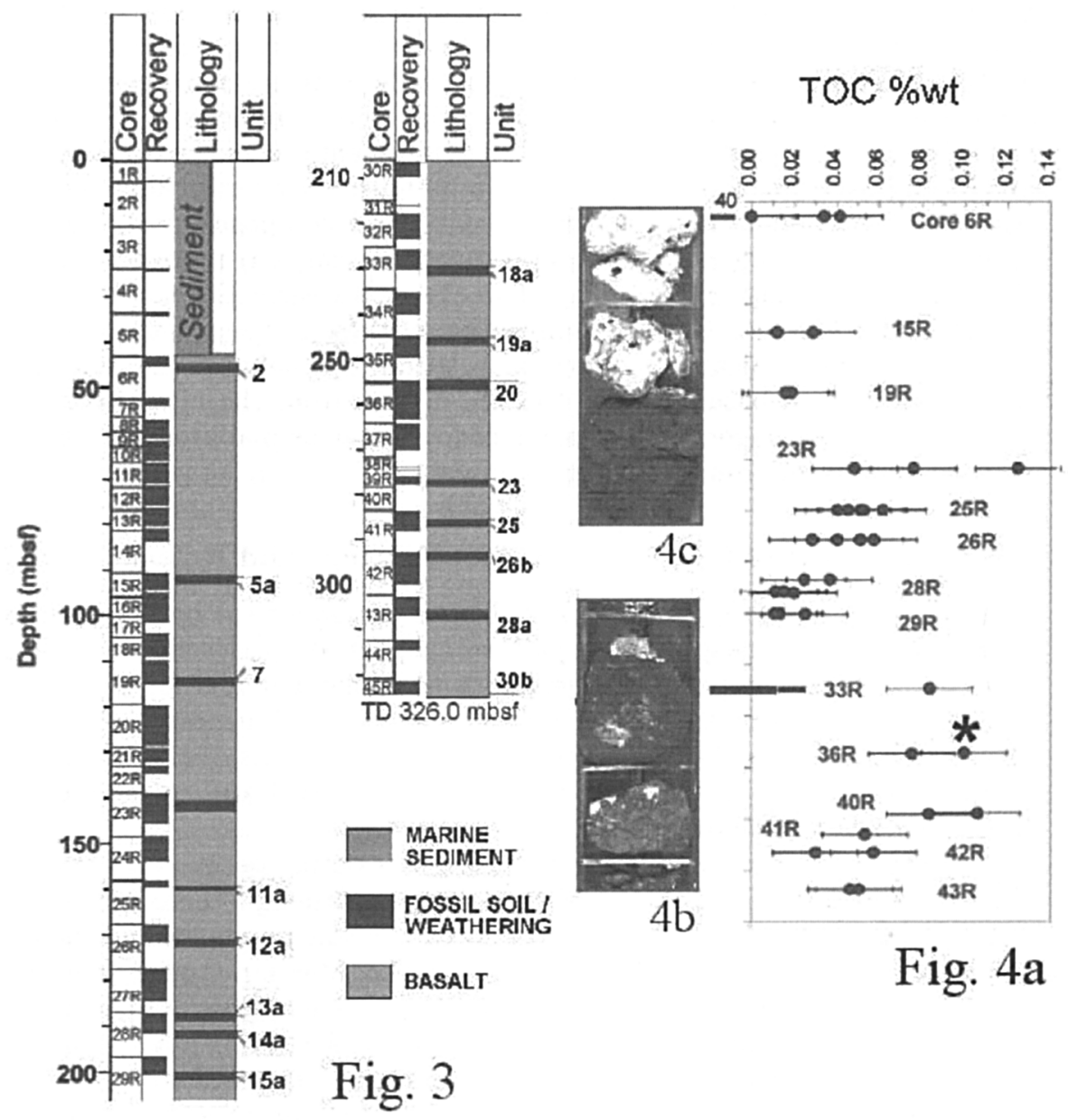

Figure 3. Stratigraphy of Hole 1205A (326.0 of total depth, TD referred to Fig. 2 and Fig. 5 (after Tarduno et al. 2002). Sediment (Cores $1 \mathrm{R}$ to $5 \mathrm{R}$ ) is above basement that starts at Core $6 \mathrm{R}$ (a. $47 \mathrm{mbsf}$ ). Only fossil soil/weathered Units (thickness not to scale) are shown for subbasement lithology. Core name and core recovery (thickness to scale with the percentage of recovery for each core) are on the left-hand side of the stratigraphic column. Note that most of the paleosoil units are $>60 \mathrm{~m}$ sub-basement.

Figure 4. $\mathrm{C}_{\text {org }}$ in red claystone at Site 1205A vs. mbsf depth. Down hole distribution of \% TOC (Fig. 4a); grey dots represent cm-spaced sampling for each soil unit. The asterisk indicates the shore-based replicate measurement. Core name refers to the same core number shown in Fig. 3. Examples of soil beds in Core 197-1205A-33R-4, 18$38 \mathrm{~cm}$ (Fig. 4b), and in Cores 197-1205A-06R-3, 62-80 cm (Fig. 4c). 
structural incompleteness (e.g., Fig. 4b, and Fig. 4c). It is seems that the younger tops of these soils (type-A horizons) were, in fact, removed prior to (Premoli-Silva et al. 1993; Holmes 1995 ) and/or during drilling (Tarduno et al. 2002). Thus, most of the recovered soil beds represent the deeper, truncated sequences, in contact with the parent rock (type-C horizons). Secondly, the red soils probably underwent not only environmental changes (in paleolatitude and/or in paleoclimate) during formation, but also diagenetic changes after their burial. Therefore, it may be that amount and composition of the detected carbon (i.e., total organic carbon and carbonate carbon) represents a complex signal from such history since late Palaeocene to early Eocene(?) time. For instance, the TOC vs. $\mathrm{CaCO}_{3}$ composition of these soil sequences might reflect the varying geochemical and structural relationships between the soils and their underlying parent basalt rocks. $\mathrm{CaCO}_{3}$ derives from the alteration of basalt rather than from diagenetic alteration of fossil marine plankton (i.e., calcareous microfossil and foraminifera-barren samples).

\subsection{Detection of $\mathbf{C}_{\text {org }}$ in Subsurface Settings and Relevance to Mars}

The primary objective of this study has been to test for the presence or absence of organic matter in deeply buried paleosoil and igneous-derived weathered rocks. A second, not less important objective is to frame a model for a deep system that remained decoupled from the Earth's oceans and atmosphere for millions of years. Such a model could serve then as a useful Mars analog for subsurface remains of a martian -biosphere that has been buried and remains decoupled from the surface of Mars.

There are major differences and analogies existing between the present-day climates and settings of the Earth and Mars. Although those differences will not be addressed extensively here, the most relevant points are outlined below.

Specifically, the composition and thickness of Martian atmosphere; the lacking of shielding from UV, and the occurrence of extremely oxidant/superoxidant conditions strongly affect chemical and geochemical reaction at the soil near surface (e.g., no-preservation of complex organics, and formation of oxy-clays and oxy-palagonite compounds). Furthermore, low temperatures and quite low atmospheric pressure prevent the stability of liquid water with the rapid formation of solid water that easily sublimates to the atmosphere (thus no near-surface lakes, rivers and oceans).

In addition to the extreme differences existing between present-day Earth and present day-Mars, there could be lesser obvious, potential differences in their wetter-warmer past counterparts. Regardless of their age, for instance, the early Tertiary fossil soil from the Pacific might retain just a different type or amount of soil organic matter (SOM) (e.g., a complex mixture of plant-derived/bacterialderived SOM) with respect to their early Mars soil counterparts (e.g., only bacterial-derived SOM) formed in wetter and warmer conditions.

Regarding the fossil soils from Site 1205, although $50 \%$ of the samples contain an amount of $\mathrm{C}_{\text {org }}$ close to the detection limit, the remaining $50 \%(\mathrm{n}=18)$ contains reliable amounts of $\mathrm{C}_{\text {org }}(0.04 \%$ to $0.12 \%)$, which are three to ten times above that limit ( 0.036 to $0.124 \%$ wt, respectively). Thus, the presence of $\mathrm{C}_{\text {org }}$ in Hole 1205A (Fig. 4a), although quite low, is meaningful enough for the purposes of this study. The finding of very low but detectable and replicable 
amounts of bulk $\mathrm{C}_{\text {org }}$ in deeply buried paleosoil/rock material, is relevant to the future search and identification of organic sources in materials recovered from the deep Earth ${ }^{1}$ and as a model for subsurface Mars (Mancinelli 2000). Most importantly, the sub-basement fossil soil cored at Site 1205 and Site 1206 underwent decoupling (i.e., burial rate $>>$ than subsidence rate) from both the Earth's atmosphere and the ocean (Fig. 3, and Fig. 5).

As a result, any detectable evidence of $\mathrm{C}_{\text {org }}$ could make those igneousderived deep paleosoils one of the best models available for soil on Mars and future investigations focused on the detection of organic material buried and preserved beneath the surface of Mars. Indeed, if past life on Mars left such traces, those might still be present within a few-to-ten of meters below the regolith surface e.g. (Kanavarioti \& Mancinelli 1990; Mancinelli 2000). Near surface tropical soils are thought to represent terrestrial counterparts (Keszthely et al. 2000; Paepe \& Van Overloop 2002) of the Martian soils analysed during the Viking (Baird et al. 1976; Clark et al. 1982), and Mars Pathfinder (Rieder et al. 1997; Dreibus et al. 1998) missions. These soils were also interpreted as alteration products of mafic igneous rocks/flood basalt. Specifically, Viking Landers data lead to two different compositional models for the present soils, which consist of a) largely Fe-rich clays or (b) palagonite ash e.g. (Carr 1999). More recently, IR spectra emphasized a widespread presence of palagonite on the Mars surface. This poorly crystalline, partly hydrated weathering product (mineraloid) has long been suggested as a Visible and near-IR (VNIR) spectral analogue of some bright regions on the Mars surface (Morris et al. 2003). Furthermore, palagonitic rock rinds would possibly explain for both VNIR, and Thermal Emission Spectrometer (TES) spectra of Martian dark regions. Those comparative studies use surface soils from Mauna Kea volcano as analogs for spectroscopic comparisons with mineralogical composition of the Mars surface (Morris et al. 2003).

Furthermore, as interaction between bacteria and igneous-derived substratum (i.e., "palagonitization" of basaltic glass) occurs in the deep Earth e.g. (Furnes et al. 2001), bio-interaction with similar igneous-derived material might occur also in deep Martian soil/regolith. This scenario would be more plausible if sufficient shielding from UV radiation and an appropriate energy source for the metabolic activity of bacteria were available beneath the Mars surface.

The presence of $\mathrm{C}_{\text {org }}$ in Hole 1205A likely reflects a complex history of paleosoil formation and diagenesis over time. Unravelling such complexity from paleosoils formed on Earth ${ }^{1}$ could be also relevant to the understanding of potential paleosoil sequences formed on $\operatorname{Mars}^{1}$ ( also Dreibus et al. 1998). Furthermore, the expertise gained working with extremely low TOC material on Earth would be useful for analogous work on Mars, where it would be reasonable to expect just trace amounts of organic matter in the highly oxidized near-surface material e.g. (Mancinelli 2000).

${ }^{1}$ http://expet.gps.caltech.edu/Hawaii_project.html 


\subsection{Model of Leg 197 Volcanic Sections \& Sources of $\mathbf{C}_{\text {org }}$ in Fossil Soil}

In this section I draft a model for ocean/atmosphere-decoupled soils and outline some implications of such decoupling for the preservation of organic sources in sub-basement settings. This model would include a) subaerial soil formation; b) soil decoupling from the early Tertiary atmosphere prior to complete subsidence below sea level $(\sim 1-2 \mathrm{Ma}$ ); and c) soil decoupling from the ocean (for $\sim 53-54$ Ma till present).

1 Subaerial soil formation. Red-brown soil horizons were formed on the top of subsiding islands by subaerial weathering, rather than hydrothermal weathering (Premoli-Silva et al. 1993; Holmes 1995), of lava flow tops or basaltic ashes during growth phases of the Nintoku and Koko Seamounts (emergent submarine volcano) and an interval of time thought to be characterized by lower eruption rates (Tarduno et al. 2002; Premoli-Silva et al. 1993; Holmes 1995). The massive mottled red-brown claystones from the Pacific are typical of tropical-subtropical soils, and their clay mineral assemblage (i.e., smectite, kaolinite, gibbsite) indicates pedogenic oxic horizon formed at least several tens of meters of elevation in lowland/upland areas (Holmes 1995) such as those present in the Hawaiian islands today.

2 Soil decoupling from the atmosphere and the ocean. After their formation, the soil horizons were subsequently buried by several meter-thick lava layers flowing from land into water in a near shore environment (Fig. 5). However, soils at Site 1205 and Site 1206 are barren of marine microfossil (Tarduno et al. 2002; Holmes 1995), i.e., Nannoplankton, Diatoms, and Foraminifera. In addition, they have a stratigraphic position that is tens to hundreds of meters beneath marine deposits and weathered basalt rock (Fig. 2, and Fig. 3). Together, these two pieces of evidences would indicate that no direct contact between the soil and lagoon/open seawaters occurred at the time of Site 1205 and Site 1206 submergence. Decoupling from the ocean water probably occurred as a result of topographic, stratigraphic and tectonophysic factors. These would have included, the topographic (upland) location of soils (Fig. 5),and, their deep setting (overlain by meters of lava flows; Fig. 2, and Fig. 3). Lava flow accumulation would imply burial rates ${ }^{2}$ of $\sim 4$ to $25 \mathrm{~m}$ per $1000 \mathrm{yr}$ that are faster than averaged subsidence rates (e.g., the present-day subsidence rate ${ }^{3}$ is estimated to be between $2.0 \mathrm{~mm} / \mathrm{y}$ and $2.5 \mathrm{~mm} / \mathrm{y}$ ). It appears likely, fossil soils penetrated during Leg 197 were already buried (Fig. 5) prior to the islands subsidence below sea level (Fig. 2) as is observed for the fossil soil units cored beneath the Mauna Kea today. This model is supported by the finding of weathered lava flows/red-brown soil recovered by the Hawaii Scientific Drilling Project (HSDP). In fact, those a. $600000 \mathrm{y}$-old soils are deeply buried beneath the flank of Mauna Kea and seem to share stratigraphic, petrologic, and textural features with their counterparts from Leg 197.

As a volcanic island moves away from its hotspot, the eruption rate slows down until the volcano becomes dormant and accumulation of lava stops. Thus,

\footnotetext{
${ }^{2}$ http://expet.gps.caltech.edu/Hawaii_project.html

${ }^{3}$ see above footnote and http://walrus.wr.usgs.gov/pacmaps/mi-fig1.html
} 


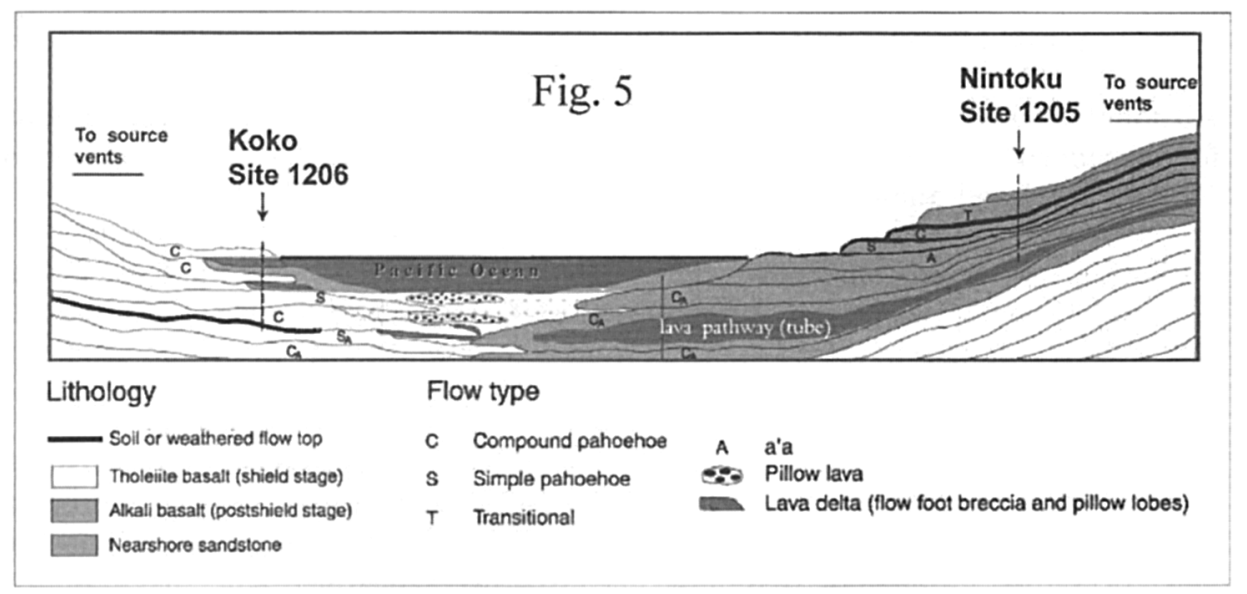

Figure 5. Models of the inferred volcanic environments for the volcanic sections drilled during Leg 197 (after Tarduno et al. 2002).

as the Nintoku and Koko Seamounts subsided below sea level, it is expected that the buried soils maintained their isolation from the Pacific Ocean because of their complete submergence (at 53-54 Ma) before the drilling of Leg 197.

\subsection{Potential Sources of $\mathrm{C}_{\text {org }}$ in Fossil Soil}

The model proposed above for the volcanic environments (Fig. 5; Tarduno et al. 2002) could provide some clues as to the expected sources of organic material (i.e., primary, secondary, terrestrial and/or marine). In fact, TOC data alone is inadequate for distinguishing different sources of organic matter. More information is needed to constrain those sources. Throughout their history these soils underwent a variety of (sometimes extreme) conditions. Some of these might include a) high temperatures/baking by overrunning lava flows prior to burial (Fig. 5) (although, since then, soils have likely not experienced $\mathrm{T}>20$ $\left.{ }^{\circ} \mathrm{C}\right)$; b) high pressures caused by burial beneath hundreds of meters of overlying rocks and sediment (Fig. 3); and c) no sun light for million of years ( 53.6-54.7 Ma) after burial and subsidence.

Those conditions probably altered the pristine organic composition (e.g., just $100-150^{\circ} \mathrm{C}$ can produce breakdown of organic matter to hydrocarbons) and structure of the red claystone, causing differences from their still exposed typical tropical counterparts (e.g., red-brown Hawaiian Oxisols, "ortox", (Soil Survey Staff 1975)). The removal of plant-derived $\mathrm{C}_{\text {org }}$ and replacement with secondary bacterial sources is one possibility. In fact, since bio-alteration of basaltic glass ("palagonitization") by bacteria is well known in glass from pillow lavas (i.e., Hole 896) (Furnes et al. 2001), $\mathrm{C}_{\text {org }}$ in soil horizons from Leg 197 could have some bacterial source. 


\section{Conclusions and Future Study}

Although differences exist between Earth soil and Martian regolith/soil, reasons for considering the sub-basement Fe-oxide-rich red paleosoils from Leg 197 as reliable Mars soil analogues include:

- they are weathering products of mafic igneous rocks and flood basalt as well as their alteration products (i.e., palagonite) are similar to those analysed/remotely detected on Mars (and whose weathering produced the Martian regolith).

- they can preserve low-organic traces in a deep earth system $(\sim-240$ to $\sim-300 \mathrm{~m}$ below volcanic basement) which remained isolated (no sun light, and reducing condition) and decoupled from the earth atmosphere and the ocean for millions of years (e.g., isolated deep biosphere).

- owing to their iron-bearing to palagonite-rich composition, they have the potential to support "glass-eating" (e.g., Furnes et al., 2001) bacteria (and perhaps Fe-Mn reducers) which are expected in both terrestrial and Mars igneous-derived paleosoils.

- the soil samples underwent initial heating by overrunning lava flows that may have removed/altered the original soil organic matter (e.g., plantderived, humic-like organics and former microbial communities) throughout. These heating effects could be understood on those soil samples and then applied to Mars.

- bacterial-induced changes in the pristine organic composition are expected, but these changes took place in a relatively closed system and consequently will be easier to unravel.

- they are relatively rare in geologic collections (Holmes 1995), and difficult to access (they are deeply buried) and sample (only from deep drilling, e.g., DSDP/ODP) as it would be expected of subsurface Mars soils.

Elemental and stable isotope analyses (EA-IRMS) of organic carbon and nitrogen $\left(\delta^{13} \mathrm{C}_{\text {org }}\right.$ and $\left.\delta^{15} \mathrm{~N}_{\text {tot }}\right)$ in samples from Hole $1206 \mathrm{~A}$ are underway to constrain the primary and secondary sources of organics and establish the potential for the red soils to preserve signatures of past and extant life. Such an objective is demanded for geomicrobiology study of subsurface/Deep Biosphere systems of Earth and Mars. This is a rapidly evolving field, which, together with more links to the Astrobiology Program could become one of the primary targets of the future Integrated Ocean Drilling Program (IODP) ${ }^{4}$.

Acknowledgments. This research used samples and data provided by the Ocean Drilling Program (ODP). ODP is sponsored by the U.S. National Science Foundation (NSF) and participating countries under management of Joint Oceanographic Institutions (JOI), Inc. Funding for this research was provided by

${ }^{4} \mathrm{http}: / /$ www.iodp.org:16080/iwg 
Italian Research Council - CNR (Italian participation to ODP). Special thanks to A. Brambati (University of Trieste, DiSGAM) and I. Premoli-Silva (University of Milano) for making possible my participation to the ODP Leg 197. I am deeply grateful to the whole Leg 197 Science Shipboard Party (SSP) and J/R Crew for their valuable collaboration and the excellent assistance with sample preparation and shipboard analyses, respectively, and to C. Brun for assistance with the EA-IRMS. I am grateful to S. Conway Morris (University of Cambridge) for his prompt review that improved the quality of this paper. Special thanks to D.W. Scholl (USGS/ODP) and many SSP, F. Drake (SETI Institute), R. L., Mancinelli (SETI Institute/NASA Ames Research Center -ARC), C.P. McKay (ARC), A. Allwood (Macquarie University), R. Paepe (Geobound International), and D.S. McKay (NASA Johnson Space Center - JSC) for reviews of this manuscript and valuable inputs on Leg 197 issues and Mars-related matter. Elemental analyses granted by Geokarst Engineering, S.r.l Area Science Park (L. Ballarin) are also acknowledged.

\section{References}

Baird, A. K., et al., 1976, Science, 194, 1288

Bonaccorsi, R. 2002, EOS Trans AGU, Fall Meet. Suppl., 83, 47

Carr, M. H. 1999, in Encyclopedia of the Solar system (Academic Press) 291, http://www.academicpress.com/refer/solar/Contents/solarch12.pdf

Clark, B. C., et al. 1982, Chemical-Composition of Martian fines, J. Geophys. Res, 87, 59

Dreibus, G., et al. 1998, Chemistry of Rocks and Soil at Ares Vallis in Comparison to Martian Meteorites, 1998 AGU Spring Meeting

Furnes, H., et al. 2001, Bio-interaction with basaltic glass and its importance in mapping the depth of oceanic biosphere, GSA 2001 Annual Meeting

Gilmore, M. S. et al. 1998, Mars 2001 Landing Site Selection, 1998 AGU Spring Meeting.

Holmes, M. A. 1995, Pedogenic alteration of basalts recovered during Leg. 144, in Proc. of the Ocean Drilling Program 1995, ed. Haggerty, J. A., Premoli-Silva, I., Rack, F., \& McNutt, M. K., 144, 381

Kanavarioti, A., \& Mancinelli, R. L. 1990, Icarus, 84, 196

Karpoff, A. M. 1980, The claystone layer between the two basalt flows in Hole 432A: an argument for the emergence of Nintoku Seamount, in Jackson, E. D., Koizumi, I., et al., Init. Repts. DSDP, 55: Washington, 707

Keszthely et al. 2000, J. Geophys. Res., 105, 15027

Mancinelli, R. L 2000, Planet. Space Sci., 48, 1035

Morris R. V. et al. 2003, Palagonitic Mars from rock rinds to dust: evidence from visible, near-IR, and Thermal emission spectra of poorly crystalline materials, http://www.lpi.usra.edu/meetings/lpsc2003/pdf/1874.pdf

Morrison, D., \& Schmidt, G. K. 1999, NASA Astrobiology Roadmap, ARC, (Moffet Field, CA), 44 pp. 
Paepe, R. R., \& Van Overloop, E. S. 2002, Red soils on Earth as a model for Mars, Instruments, Methods, and Missions for Astrobiology V - Proceedings of SPIE, Vol. \#4859 [4859-12]

Premoli-Silva, I., et al. 1993, Shipboard Scientific Party, 1993a Site 871, in Proc. ODP, Init. Repts., 144, College Station, TX (ODP), 41

Rieder, R., et al., 1997, Science, 278, 1771

Shipley, T. H., et al. 1995, Proc. ODP, Init. Repts., 156, College Station, TX (ODP)

Soil Survey Staff 1975, Soil Taxonomy: Washington (U.S. Govt. Printing Office), Dept. of Agriculture. Handbook N.o 436

Tarduno, J. A., et al. 2002, Proc. ODP, Init. Repts., 197, http://www-odp.tamu.edu/publications/197_R/197ir.htm

Zent, A. P., \& McKay, C. P. 1994, Icarus, 108, 146 